\title{
Stigma terhadap Orang dengan Gangguan Mental: Pengaruh informasi status gangguan mental terhadap penilaian daya tarik fisik pada mahasiswi S1 Psikologi
}

\author{
Althea Mutiara Celina \& Retha Arjadi* \\ ${ }^{1}$ Fakultas Psikologi, Universitas Katolik Indonesia Atma Jaya, Jakarta Selatan, DKI Jakarta
}

\begin{abstract}
Abstrak
Penelitian ini bertujuan untuk melihat pengaruh informasi tentang status gangguan mental terhadap penilaian daya tarik fisik pada mahasiswi S1 Psikologi, dengan sampel mahasiswi S1 Fakultas Psikologi Unika Atma Jaya. Penelitian menggunakan metode randomized pretestposttest control group design dengan teknik kontrol blocking. Pemberian pretest-posttest menggunakan visual analogue scale dilakukan untuk mengukur penilaian partisipan atas daya tarik fisik objektif dan subjektif dari model laki-laki yang ditampilkan melalui foto. Di kelompok eksperimen ( $n=31$, Mean usia=20,48, $S D=1,18$ ), partisipan diberikan informasi yang menunjukkan bahwa model memiliki gangguan mental skizofrenia, sedangkan di kelompok kontrol $(n=32$, Mean usia=20,59, $S D=1,13)$, partisipan diberikan informasi yang menunjukkan bahwa model sehat secara mental. Hasil penelitian menunjukkan bahwa informasi status gangguan mental berpengaruh secara signifikan pada penilaian daya tarik fisik secara objektif $(U=405.000, n 1=31, n 2=32, p<0,05)$ dan subjektif $(U=116.000, n 1=31, n 2=32, p<0,05)$. Pada post-test, skor daya tarik fisik model menurun secara signifikan pada kelompok eksperimen dibandingkan dengan kelompok kontrol, baik secara objektif maupun subjektif. Ini menunjukkan bahwa mereka yang mempelajari ilmu Psikologi tidak sepenuhnya dapat memandang individu dengan gangguan mental secara netral dalam konteks yang personal, dalam hal ini ketertarikan fisik dalam konteks romantis. Studi lanjutan pada topik ini masih diperlukan.
\end{abstract}

Kata kunci: Pengetahuan, status mental, gangguan mental, daya tarik fisik

\begin{abstract}
This study aims to see the effect of information about mental disorder status on physical attractiveness in Psychology bachelor female students, with a sample group from the Faculty of Psychology, Atma Jaya Catholic University of Indonesia. We used a randomized pretestposttest control group design with a blocking control technique. Pretest-posttest measures using a visual analog scale to assess objective and subjective physical attractiveness of the male model photograph were conducted. In the experimental group $(n=31$, Mean age $=20.48$, $S D=1.18)$, participants were informed that the model had schizophrenia, while in the control group $(n=32$, Mean age $=20.59, S D=1.13)$, participants were informed that the model was mentally healthy. The results showed that the information of mental disorder status had a significant effect on the objective $(U=405,000, n 1=31, n 2=32, p<0.05)$ and subjective $(U=116,000, n 1=31, n 2=32, p<0.05)$ assessment of physical attractiveness. At posttest, the objective and subjective physical attractiveness scores decreased significantly in the experimental group compared to the control group. This indicates that those who study psychology may not fully have a neutral view on individuals with mental disorders in personal context like romantic physical attraction. Further study on this topic is needed.
\end{abstract}

Keywords: Knowledge, mental status, mental disorder, physical attractiveness

\section{Pendahuluan}

Kesehatan merupakan salah satu aspek yang berkontribusi dalam meningkatkan rasa ketertarikan romantis, khususnya pada perempuan.

Naskah masuk: 31 Agustus 2020

Naskah diterima: 7 Desember 2020
Teori evolusi menjelaskan bahwa perempuan harus memaksimalkan "modal" untuk menurunkan gennya dalam menghasilkan keturunan (Trivers dalam Shoemake, 2007). Buss dalam Boysen (2017) mengatakan bahwa kesehatan menjadi aspek penting yang dicari oleh perem-

* Fakutas Psikologi, Universitas Katolik Indonesia Atmajaya Jl. Jend. Sudirman No. 51, Kota Jakarta Selatan, DKI Jakarta, 12930 E-mail: retha.arjadi@atmajaya.ac.id 
puan dalam pasangannya, karena individu dengan kesehatan yang baik memiliki risiko yang rendah terhadap penyebaran penyakit dan dapat menghasilkan keturunan yang sehat. Perempuan akan lebih sulit untuk tertarik pada individu dengan kesehatan yang kurang baik. Kesehatan dalam hal ini tidak hanya merujuk pada kesehatan fisik saja, tetapi juga kesehatan mental.

Berdasarkan survei yang dilakukan oleh Time to Change (2010), sebuah lembaga sosial yang bergerak di bidang kesehatan mental, individu dengan gangguan mental cenderung ditolak saat kencan (44\%) dibandingkan individu dengan gangguan kesehatan fisik (19\%). Di Asia sendiri, gangguan mental seringkali dianggap sebagai sesuatu yang menyimpang dan aib karena sebagian besar budayanya sangat mengedepankan nilai-nilai yang sesuai dengan norma sosial dan kontrol diri secara emosional (Abdullah \& Brown, 2011). Hal ini dikarenakan gangguan mental dapat berdampak pada penurunan fungsi personal individu seperti regulasi emosi atau perilaku, pengambilan keputusan, penalaran, memori, serta terganggunya fungsi interpersonal dalam berinteraksi maupun menjalin relasi dengan orang lain (American Psychiatric Association, 2013).

Tidak hanya itu, gangguan mental juga bisa berdampak pada penampilan fisik seseorang. Sebagai contoh, individu dengan gangguan mental yang memiliki gejala negatif (berkurangnya minat untuk melakukan hal-hal yang biasa dilakukan individu pada umumnya) seperti skizofrenia, cenderung menunjukkan pola kebersihan yang buruk, perawatan diri yang buruk, sehingga dapat dipersepsikan sebagai individu yang tidak menarik oleh orang-orang di sekitarnya. Selain itu, gejala gangguan mental seperti kurang tidur juga dapat mengurangi daya tarik fisik pada individu (Axelsson dkk., 2010). Padahal, daya tarik fisik merupakan aspek yang juga perlu dipertimbangkan dalam ketertarikan romantis (Buss dalam Shoemake, 2007).

Kedua aspek yang menjadi pembahasan saat ini, yaitu kesehatan mental dan daya tarik fisik, juga memiliki kaitan tersendiri. Penelitian oleh Feingold (1992) menunjukkan bahwa individu yang menarik secara fisik dipersepsikan lebih sehat secara mental dibandingkan individu yang tidak menarik secara fisik. Individu dengan daya tarik fisik yang tinggi pun dinilai memiliki kelebihan dalam sejumlah aspek, mencakup tingkat kebahagiaan, kepandaian, keterampilan sosial, kemampuan menjadi partner, serta kesuksesan dalam pekerjaan (Dion dkk., 1972; Eagly dkk., 1991; Langlois dkk., 2000). Laki-laki umumnya diharapkan memiliki peran sebagai pemberi nafkah yang baik dalam keluarga (Loscocco \& Spitze, 2007), dan kelebihankelebihan tersebut dapat mendukung peran yang dimaksud. Oleh karena itu, daya tarik fisik yang erat kaitannya dengan berbagai kelebihan tersebut dapat dijadikan pertimbangan oleh perempuan saat memilih laki-laki untuk menjadi pasangannya.

Di sisi lain, studi yang dilakukan oleh Farina dkk. (1977) menunjukkan bahwa pasien gangguan mental secara umum dilihat sebagai individu yang kurang menarik secara fisik daripada individu yang tidak memiliki status gangguan mental. Menurut Jonason dkk. (2015), dalam memilih calon pasangan, individu lebih menitikberatkan penilaiannya pada karakteristik yang dihindari dibandingkan karakteristik yang diinginkan. Hal ini sejalan dengan teori prospek yang dikemukakan oleh Kahneman dan Tversky (1979) dan bias negatif yang dikemukakan oleh Rozin dan Royzman (2001), bahwa individu lebih mementingkan informasi yang negatif dibandingkan informasi yang positif dalam mengevaluasi sesuatu. Individu dengan gangguan mental dinilai memiliki karakteristik yang negatif dari segi kesehatan dan kepribadian, sehingga meskipun memiliki daya tarik fisik yang tinggi, penilaian daya tarik fisik terhadap individu dengan gangguan mental dapat terpengaruh bias dan menjadi kurang akurat.

Selain persepsi mengenai daya tarik fisik, beberapa atribut negatif yang dikaitkan pada individu dengan gangguan mental antara lain berbahaya, kotor, lemah, bodoh, dan dingin (Link dkk.; Nunnally; Olmsted \& Durham dalam Phelan \& Link, 2004). Atribut-atribut ini dapat menyulitkan individu dengan gangguan mental saat mencari pasangan. Atribut yang dikaitkan pada individu atau sebuah kelompok dapat muncul karena seseorang cenderung melakukan kategorisasi pada orang-orang di sekitarnya. Kategorisasi dibuat berdasarkan informasi yang diperoleh saat berinteraksi dengan orang lain, baik dalam bentuk tampilan fisik maupun tandatanda lainnya yang terlihat dan diingat (Fiske \& Neuberg dalam Matusitz, 2012).

Banyak orang masih memiliki pengetahuan yang minim akan gangguan mental (Jorm dkk., 2006), dan individu cenderung menggunakan "jalan pintas" untuk melakukan penilaian jika dirinya tidak memiliki pengetahuan yang memadai (Sternberg \& Sternberg, 2011). Pengetahuan dalam hal ini bisa merujuk pada kurangnya informasi mengenai definisi gangguan mental itu sendiri, jenis-jenisnya, gejala-gejalanya, sampai pada penanganannya. Berdasarkan ini, masyarakat akan menilai individu dengan gangguan mental atas karakteristiknya yang paling menonjol yaitu yang bersifat negatif.

Dari sini menjadi jelas bahwa pengetahuan yang dimiliki individu menjadi aspek yang penting dalam menilai orang lain. Ward dalam 
Matusitz (2012) menyatakan bahwa dengan banyaknya pengetahuan, individu dapat lebih memahami dan menghargai orang lain. Dengan kata lain, semakin banyak pengetahuan yang dimiliki individu mengenai gangguan mental, maka semakin sedikit penilaian negatif yang ditunjukkan pada individu dengan gangguan mental, dan sebaliknya. Atas dasar tersebut, pada penelitian ini, peneliti memilih partisipan penelitian dari kelompok yang memiliki sumber pengetahuan yang terpercaya mengenai gangguan mental, yaitu mahasiswi S1 jurusan Psikologi.

Selain pengetahuan mengenai status gangguan mental, terdapat juga variabel lain yang dapat mempengaruhi daya tarik fisik individu dengan gangguan mental, yaitu stigma. Pengetahuan yang dimiliki individu terkait gangguan mental tersebut dapat membentuk suatu keyakinan terhadap gangguan mental, baik secara positif maupun negatif. Keyakinan negatif yang dimiliki individu pun dapat berkembang menjadi sebuah stigma. Orang-orang dengan gangguan mental merupakan kelompok masyarakat yang paling rentan untuk mendapatkan stigma (Overton \& Medina, 2008). Stigma yang ditunjukkan pada individu dengan gangguan mental pada umumnya antara lain tidak dapat diprediksi, tidak layak, tidak berguna, tidak dapat menjadi anggota masyarakat yang produktif, dan tidak menarik (Wahl dkk., 2012). Stigma gangguan mental sangat mungkin menurunkan penilaian seseorang terhadap orang lain dengan gangguan mental, tidak terkecuali pada daya tarik fisiknya. Oleh karenanya, peneliti melihat bahwa stigma individu terhadap gangguan mental menjadi variabel yang penting untuk dikontrol dalam penelitian ini.

Pada penelitian ini, penilaian daya tarik fisik kemudian terbagi lagi ke dalam dua aspek, yaitu secara objektif dan subjektif. Penilaian ini dapat dijelaskan dengan pendekatan dual-process theory. Menurut teori ini, manusia menggunakan dua proses kognitif untuk penilaian dan pengambilan keputusan, yang sering disebut dengan istilah "Sistem 1" dan "Sistem 2". Perbedaannya adalah, "Sistem 1" bersifat otomatis, di luar kesadaran, membutuhkan sedikit usaha, dan berlangsung cepat, sedangkan "Sistem 2" sifatnya lebih terkontrol, di bawah kesadaran, membutuhkan lebih banyak usaha, dan berlangsung lama (Gawronski \& Creighton, 2013).

Saat menggunakan "Sistem 1", penilaian bersifat lebih objektif dikarenakan adanya reaksi serupa yang ditunjukkan oleh individu saat melihat wajah dengan daya tarik fisik yang tinggi karena hal tersebut terbukti dapat mengaktifkan reward center pada otak manusia (Aharon dkk.; O'Doherty dkk. dalam Rhodes, 2006).
Sebaliknya, saat menggunakan "Sistem 2", penilaian bersifat lebih subjektif karena lebih melibatkan komponen afektif dan motivasi dalam diri individu yang cara kerjanya pun berbeda pada setiap manusia. Kedua hal ini diperlukan dalam penelitian ini karena penilaian "tampan" dan "menarik" mungkin memiliki tingkat yang berbeda ketika dipengaruhi oleh pengetahuan mengenai status gangguan mental.

Penelitian ini bertujuan untuk mengetahui pengaruh informasi tentang status gangguan mental terhadap penilaian daya tarik fisik individu pada mahasiswi S1 Psikologi. Dengan kata lain, peneliti ingin melihat hubungan sebab akibat pada kedua variabel, yaitu apakah informasi tentang status gangguan mental dapat mempengaruhi penilaian terhadap daya tarik fisik. Gangguan mental yang dimaksud dalam penelitian ini dispesifikkan menjadi gangguan mental skizofrenia karena gejala-gejala skizofrenia terlihat lebih menonjol dibandingkan gangguan mental lainnya, misalnya gejala dalam bentuk halusinasi dan delusi (American Psychiatric Association, 2013). Dengan mengangkat gangguan mental skizofrenia yang gejala-gejalanya terbilang eskplisit ini, kemungkinan terjadinya ambiguitas pemahaman mengenai gangguan mental antarpartisipan penelitian akan dapat diminimalisir.

\section{Metode Penelitian}

\section{Desain}

Penelitian ini menggunakan metode eksperimen dengan randomized pretest-posttest control group design. Terdapat dua kelompok penelitian, yaitu kelompok eksperimen dan kelompok kontrol. Kedua kelompok diminta untuk memberi penilaian mengenai daya tarik fisik pada foto seorang laki-laki yang sama. Sedangkan pada kelompok eksperimen, diberikan perlakuan berupa manipulasi variabel bebas (informasi bahwa laki-laki pada foto memiliki gangguan mental), dan pada kelompok kontrol diberikan perlakuan netral (informasi netral bahwa lakilaki pada foto memiliki kondisi yang sehat dan dapat menjalani fungsi-fungsi kesehariannya dengan baik). Variabel terikat pada penelitian ini adalah penilaian daya tarik fisik. Variabel terikat ini diukur dua kali, yaitu sebelum diberikan perlakuan dan setelah diberikan perlakuan pada masing-masing kelompok. Dapat dilihat pada Gambar 1. 
Gambar 1.

Randomized Pretest-Posttest Control Group Design

$\mathrm{R}(\mathrm{KE}) \longrightarrow \mathrm{X} \longrightarrow \mathrm{O}_{2}$
$\mathrm{R}(\mathrm{KK}) \longrightarrow \mathrm{O}_{2}$
$\mathrm{O}_{1} \longrightarrow \mathrm{C}$
$\mathrm{R}=$ randomisasi
$\mathrm{KE}=$ kelompok eksperimen
$\mathrm{KK}=$ kelompok kontrol
$\quad \mathrm{O}_{1}=$ pretest
$\mathrm{X}=$ perlakuan
$\mathrm{O}_{2}=$ posttest

Desain penelitian ini diadaptasi dengan sejumlah penyesuaian dari penelitian eksperimen Farina dkk. (1977) yang bertujuan melihat kaitan antara gangguan mental dan daya tarik fisik, dengan melibatkan partisipan masyarakat umum berjenis kelamin laki-laki dan perempuan. Berbeda dengan penelitian kali ini, pada penelitian Farina dkk. (1977), partisipan pada kelompok eksperimen diminta memberikan penilaian daya tarik fisik terhadap foto perempuan yang merupakan pasien gangguan mental, sedangkan partisipan pada kelompok kontrol diminta memberikan penilaian daya tarik fisik terhadap foto perempuan yang merupakan staf di sebuah universitas.

\section{Partisipan}

Partisipan penelitian ini adalah mahasiswi S1 jurusan Psikologi, dengan sampel penelitian 63 mahasiswi aktif S1 Fakultas Psikologi Unika Atma Jaya (FPUAJ). Partisipan memiliki rentang usia 18-23 tahun dan berorientasi heteroseksual. Pada kelompok eksperimen, 58\% beretnis Tionghoa, 26\% beretnis Jawa, serta 16\% etnis lainnya yang terdiri dari etnis Minang, Padang, dan Sunda. Pada kelompok kontrol, 53\% beretnis Tionghoa, 28\% beretnis Jawa, serta $19 \%$ etnis lainnya yang terdiri dari etnis Ambon, Batak, Dayak, Manado, Minang, dan Sunda. Seluruh partisipan telah menandatangani informed consent untuk menyatakan kesediaan terlibat dalam penelitian ini. Penelitian ini juga telah mendapatkan persetujuan etik dari Komisi Etika
Penelitian Unika Atma Jaya (nomor surat 0584/III/LPPM-PM.10.05/05/2019). Partisipan penelitian dipilih menggunakan stratified sampling, yaitu berdasarkan angkatan (angkatan 20152018). Data demografis partisipan dapat dilihat pada Tabel 1.

\section{Kontrol}

Peneliti melakukan teknik blocking berdasarkan level stigma yang tinggi dan rendah sesuai skor yang diperoleh partisipan pada kuesioner stigma gangguan mental. Kuesioner yang digunakan merupakan adaptasi dari BMI (Beliefs towards Mental Illness scale) (Hirai \& Clum, 2000). Kuesioner ini merupakan self-report berisikan 21 item untuk mengukur pandangan negatif yang dimiliki seseorang terhadap individu dengan gangguan mental yang meliputi aspek dangerousness, poor social, interpersonal skills, dan incurability, dan shame. Skala yang digunakan adalah Likert Scale yang berkisar dari 0 "sangat tidak setuju" sampai 5 "sangat setuju".

Pengujian internal consistency menunjukkan bahwa alat ukur yang digunakan valid, terlihat dari adanya korelasi yang signifikan pada setiap item $(p<0,05)$ dengan rentang korelasi sebesar 0,32 - 0,68. Pengujian reliabilitas Cronbach Alpha juga menunjukkan bahwa kuesioner memiliki reliabilitas yang baik $\left(r_{A}=0.85\right)$. Setelah mengetahui frekuensi dari masing-masing angkatan dan masing-masing level stigma, peneliti membagi partisipan secara acak ke dalam kelompok eksperimen dan kelompok kontrol. 
Tabel 1.

Data demografi partisipan

\begin{tabular}{cccc}
\hline & & KE $(\mathrm{n}=31)$ & KK $(\mathrm{n}=32)$ \\
\hline Mean umur (SD) & & $20,48(1,18)$ & $20,59(1,13)$ \\
\hline \multirow{3}{*}{ Angkatan } & 2018 & 5 & 0 \\
\cline { 2 - 4 } & 2017 & 1 & 8 \\
\cline { 2 - 4 } & 2016 & 17 & 10 \\
\cline { 2 - 4 } & 2015 & 8 & 14 \\
\hline \multirow{3}{*}{ Etnis } & Tionghoa & 18 & 17 \\
\cline { 2 - 4 } & Jawa & 8 & 6 \\
\cline { 2 - 4 } & Lainnya & 5 & 14 \\
\hline \multirow{2}{*}{ Level Stigma } & Rendah & 13 & 9 \\
\cline { 2 - 4 } & Tinggi & 18 & 18 \\
\hline
\end{tabular}

\section{Instrumen}

\section{Foto individu laki-laki yang menarik secara fisik}

Peneliti menggunakan foto laki-laki berkebangsaan Indonesia beretnis Tionghoa berusia 20 tahun yang tidak memiliki gangguan mental dan memiliki fitur wajah menarik sebagai model penelitian. Model penelitian tersebut telah mengetahui dan menyetujui bahwa fotonya akan disebarkan untuk kepentingan penelitian, melalui lembar kesepakatan yang juga telah diajukan dan disetujui oleh Komisi Etika Penelitian Unika Atma Jaya.

Foto yang digunakan merupakan foto yang sudah diujicobakan pada sampel yang dapat mewakili kelompok populasi, di luar sampel penelitian. Uji coba dilakukan kepada 23 partisipan yang berorientasi heteroseksual, $56 \%$ beretnis Tionghoa, 22\% beretnis Jawa, dan 22\% etnis lainnya yang terdiri dari dari etnis Ambon, Batak, Minang, dan Sunda. Partisipan uji coba diminta untuk memberikan ranking 1-5 terhadap lima foto laki-laki dengan fitur wajah yang peneliti rasa menarik. Lima foto laki-laki tersebut berasal dari etnis yang berbeda-beda, mencakup etnis Tionghoa, Jawa, Manado, dan Toraja. Foto yang akhirnya dipilih untuk digunakan dalam eksperimen adalah foto dengan rata-rata ranking tertinggi berdasarkan penilaian dari partisipan uji coba, yaitu sebuah foto laki-laki beretnis Tionghoa. Foto tersebut merupakan foto setengah badan dan tampak depan yang menampilkan laki-laki beretnis Tionghoa, berkulit putih, berambut hitam, alis tebal, mata kecil, dagu runcing, bahu lebar, dan berdiri tegak.

\section{Skenario berisikan informasi mengenai status mental (Manipulasi).}

Informasi mengenai gambaran status mental yang dimiliki laki-laki pada foto yang ditampilkan di kedua kelompok penelitian akan disampaikan oleh peneliti secara lisan di depan kelas secara klasikal. Pada kelompok eksperimen, partisipan diberikan informasi mengenai individu pada foto yang ditampilkan sebagai seseorang yang memiliki gangguan mental skizofrenia. Dalam informasi ini dijelaskan bahwa individu pada foto sering menampilkan gejala-gejala seperti meyakini bahwa dirinya adalah anak dari salah satu tokoh terkemuka di dunia dan berbicara dengan orang lain saat sedang sendiri, serta harus menjalani terapi di rumah sakit dan meminum obat secara rutin untuk meringankan gejala dari gangguan mental yang dimilikinya. Pada kelompok kontrol, responden diberikan informasi netral, yaitu bahwa individu pada foto yang ditampilkan adalah seseorang yang sehat dan dapat menjalani fungsi-fungsi kesehariannya dengan baik.

\section{Daya Tarik Fisik}

Penilaian daya tarik fisik yang diukur dalam penelitian ini dibedakan menjadi dua, yaitu secara objektif dan subjektif. Keduanya diukur menggunakan Visual Analog Scale (VAS). Pertanyaan pertama untuk mengukur penilaian daya tarik fisik yang objektif, berbunyi "Seberapa tampan laki-laki pada foto tersebut?" dengan skala dari 0 "sangat tidak tampan" sampai 5 "sangat tampan". Pertanyaan kedua untuk mengukur penilaian daya tarik fisik yang subjektif, berbunyi "Seberapa menarik laki-laki pada foto tersebut?" dengan skala dari 0 "sangat tidak menarik" sampai 5 "sangat menarik". 


\section{Prosedur}

Pencarian partisipan dilakukan dengan menyebarkan kuesioner mengenai stigma gangguan mental secara online melalui group chat Line di setiap angkatan dan meminta partisipan untuk mengisinya. Setelah mengetahui skor dari setiap partisipan, peneliti membagi partisipan ke dalam kelompok eksperimen dan kelompok kontrol.

Pelaksanaan eksperimen dilakukan pada bulan Mei tahun 2019 dan berlangsung selama dua hari, yaitu satu hari untuk kelompok eksperimen dan satu hari untuk kelompok kontrol. Penelitian dilakukan secara klasikal di ruang kelas di kampus Unika Atma Jaya Semanggi selama kurang lebih 30 menit, didahului dengan pemberian informed consent, baik di kelompok eksperimen maupun kelompok kontrol.

Pelaksanaan penelitian ini diawali dengan pemberian instruksi pengisian kuesioner daya tarik fisik, dilanjutkan dengan menampilkan foto laki-laki (model) tanpa informasi apapun dan pengisian kuesioner (pretest). Lembar pretest kemudian dikumpulkan oleh peneliti, lalu dilanjutkan dengan pembacaan skenario oleh peneliti. Pada kelompok eksperimen disampaikan skenario bahwa laki-laki pada foto memiliki gangguan mental skizofrenia beserta gejala-gejalanya yang mengganggu fungsi kesehariannya. Pada kelompok kontrol disampaikan skenario bahwa laki-laki pada foto memiliki kondisi mental yang sehat dan dapat melakukan fungsi sehari-hari dengan baik. Setelah skenario selesai disampaikan pada masing-masing kelompok, dilanjutkan dengan pemberian instruksi pengerjaan kuesioner daya tarik fisik, pengisian kuesioner (posttest), dan pengumpulan lembar posttest oleh peneliti.

Pada kelompok eksperimen, ada tambahan pemberian manipulation check. Manipulation check dilakukan dengan memberikan pertanyaan tertutup ("Apakah laki-laki pada foto memiliki gangguan mental") dengan pilihan jawaban "ya/tidak" dan pertanyaan terbuka ("Mengapa?") untuk memastikan bahwa partisipan di kelompok eksperimen benar-benar mengetahui bahwa individu yang ditampilkan pada foto memang memiliki gangguan mental. Terakhir, dilakukan debriefing pada kedua kelompok. Tahap pelaksanaan eksperimen dapat dilihat pada Tabel 2.

\section{Teknik Analisis}

Untuk menguji perbedaan Mean pada penilaian daya tarik fisik di kedua kelompok penelitian, digunakan teknik perhitungan MannWhitney U-test dikarenakan data tidak berdistribusi normal. Data yang digunakan adalah Mean dari selisih skor pretest dan posttest (skor posttest - skor pretest) yang didapat pada kuesioner daya tarik fisik. Jika Mean dari selisih skor pretest dan posttest di kelompok kontrol berbeda secara signifikan dari kelompok eksperimen, maka dapat dipastikan bahwa penilaian daya tarik fisik tersebut memang dipengaruhi oleh pengetahuan tentang status gangguan mental.

Tabel 2.

Tahap Pelaksanaan Eksperimen

\begin{tabular}{|c|c|c|}
\hline Waktu & Kelompok Kontrol (KK) & Kelompok Eksperimen (KE) \\
\hline 10 menit & $\begin{array}{l}\text { Pembukaan dan pengisian informed } \\
\text { consent }\end{array}$ & $\begin{array}{l}\text { Pembukaan dan pengisian informed } \\
\text { consent }\end{array}$ \\
\hline 2 menit & $\begin{array}{l}\text { Pemberian instruksi pengisian } \\
\text { kuesioner (pretest) }\end{array}$ & $\begin{array}{l}\text { Pemberian instruksi pengisian } \\
\text { kuesioner (pretest) }\end{array}$ \\
\hline 3 menit & $\begin{array}{l}\text { Pemberian foto tanpa informasi dan } \\
\text { pengisian kuesioner (pretest) beserta } \\
\text { pengumpulannya }\end{array}$ & $\begin{array}{l}\text { Pemberian foto tanpa informasi dan } \\
\text { pengisian kuesioner (pretest) beserta } \\
\text { pengumpulannya }\end{array}$ \\
\hline 5 menit & $\begin{array}{l}\text { Pemberian skenario bahwa laki-laki } \\
\text { pada foto memiliki gangguan mental } \\
\text { skizofrenia beserta gejala-gejalanya, } \\
\text { yang mengganggu fungsi hariannya }\end{array}$ & $\begin{array}{l}\text { Pemberian skenario bahwa laki-laki } \\
\text { pada foto sehat secara mental dan } \\
\text { dapat berfungsi dengan baik dalam } \\
\text { kesehariannya }\end{array}$ \\
\hline 2 menit & $\begin{array}{l}\text { Pemberian instruksi pengisian } \\
\text { kuesioner (posttest) }\end{array}$ & $\begin{array}{l}\text { Pemberian instruksi pengisian } \\
\text { kuesioner (posttest) }\end{array}$ \\
\hline 3 menit & $\begin{array}{c}\text { Pengisian kuesioner } \\
\text { (posttest) beserta pengumpulannya }\end{array}$ & $\begin{array}{c}\text { Pengisian kuesioner (posttest) beserta } \\
\text { pengumpulannya } \\
\text { dan manipulation check }\end{array}$ \\
\hline 3 menit & Debriefing & Debriefing \\
\hline 2 menit & Penutupan & Penutupan \\
\hline
\end{tabular}




\section{Hasil Penelitian}

Statistik deskriptif dari data penelitian dapat dilihat pada Tabel 3 dan 4. Dari Tabel 4 dapat dilihat bahwa mean dari selisih skor prestest posttest untuk daya tarik fisik objektif dan subjektif di kelompok kontrol yang bernilai positif menunjukkan adanya peningkatan skor pada sebagian partisipan setelah diberikan perlakuan. Sebaliknya, Mean untuk daya tarik fisik objektif dan subjektif di kelompok eksperimen yang ber- nilai negatif menunjukkan adanya penurunan skor pada sebagian partisipan setelah diberikan perlakuan berupa informasi bahwa model pada foto memiliki gangguan mental. Hal ini menunjukkan bahwa terdapat perbedaan penilaian partisipan di kedua kelompok penelitian, baik untuk penilaian daya tarik fisik objektif maupun daya tarik subjektif. Untuk melihat signifikansi dari perbedaan mean pada kedua kelompok, dilakukan uji beda Mann-Whitney U-test (dapat dilihat pada Tabel 5).

Tabel 3.

Statistik Deskriptif untuk Skor pada Daya Tarik Fisik

\begin{tabular}{cllccc}
\hline \multirow{2}{*}{ KE } & Daya Tarik Fisik Objektif & & $\mathrm{n}$ & $\mathrm{M}$ & $\mathrm{SD}$ \\
\cline { 3 - 5 } & & Pretest & 31 & 3,03 & 0,91 \\
\cline { 3 - 5 } & Daya Tarik Fisik Subjektif & Posttest & 31 & 2,90 & 0,87 \\
\hline \multirow{2}{*}{ KK } & Daya Tarik Fisik Objektif & Pretest & 31 & 2,87 & 0,99 \\
\cline { 3 - 5 } & & Posttest & 31 & 1,71 & 1,01 \\
\cline { 2 - 5 } & Daya Tarik Fisik Subjektif & Posttest & 32 & 3,31 & 0,64 \\
\hline & & Pretest & 32 & 3,38 & 0,71 \\
\hline & & Posttest & 32 & 3,91 & 0,77 \\
\hline
\end{tabular}

Tabel 4.

Statistik deskriptif untuk selisih skor pretest dan posttest pada daya tarik fisik

\begin{tabular}{clccc}
\hline & & $\mathrm{n}$ & $\mathrm{M}$ & $\mathrm{SD}$ \\
\hline \multirow{3}{*}{ KE } & Daya Tarik Fisik Objektif & 31 & $-0,13$ & 0,34 \\
\cline { 2 - 5 } & Daya Tarik Fisik Subjektif & 31 & $-1,16$ & 1,29 \\
\hline \multirow{3}{*}{ KK } & Daya Tarik Fisik Objektif & 32 & 0,06 & 0,25 \\
\cline { 2 - 5 } & Daya Tarik Fisik Subjektif & 32 & 0,75 & 0,80 \\
\hline
\end{tabular}

Tabel 5.

Mann-Whitney U-test untuk pengetahuan tentang status gangguan mental dan daya tarik fisik

\begin{tabular}{cccc}
\hline & Mann-Whitney U & $\mathrm{z}$ & Sig. \\
\hline Pengetahuan - Daya Tarik Fisik (Objektif) & 405.000 & $-2,46$ & 0,01 \\
\hline Pengetahuan - Daya Tarik Fisik (Subjektif) & 116.000 & $-5,37$ & 0,00 \\
\hline
\end{tabular}

Berdasarkan data pada Tabel 5, terlihat bahwa terdapat perbedaan yang signifikan pada selisih skor pretest - posttest di kelompok eksperimen dan kelompok kontrol untuk penilaian daya tarik fisik objektif $(U=405.000, n 1=31, n 2$ $=32, p<0.05$ ) dan juga terdapat perbedaan yang signifikan pada selisih skor pretest - posttest di kelompok eksperimen dan kelompok kontrol untuk penilaian daya tarik fisik subjektif $(U=$ 116.000, $n 1=31, n 2=32, p<0.05$ ). Hasil ini menunjukkan bahwa pengetahuan tentang status gangguan mental terbukti dapat mempengaruhi daya tarik fisik. Partisipan pada kelompok eksperimen menurunkan penilaiannya terhadap daya tarik fisik model yang disajikan pada foto, baik secara objektif maupun subjektif, setelah diberi informasi bahwa model memiliki gangguan mental, dan penurunan skor pada kelompok eksperimen ini berbeda signifikan dengan yang dilaporkan oleh kelompok kontrol.

Untuk mengetahui seberapa besar pengaruh pengetahuan tentang status mental terhadap daya tarik fisik, dilakukan perhitungan effect size dan interpretasinya (Cohen dalam Maher dkk., 2013). Hasilnya menunjukkan effect size untuk daya tarik fisik objektif ("seberapa tampan") adalah $d=0,64$ (sedang). Selain itu, didapati bahwa effect size untuk daya tarik fisik subjektif ("seberapa menarik") adalah $d=1,78$ (sangat besar). 


\section{Diskusi}

Penelitian yang melibatkan mahasiswi S1 Psikologi dengan sampel mahasiswi S1 FPUAJ memiliki hasil yang sejalan dengan penelitian Farina dkk. (1977), yang melibatkan masyarakat umum sebagai sampel penelitian. Meskipun mahasiswi S1 Psikologi memiliki pengetahuan yang lebih luas terkait gangguan mental, menerima ajaran untuk memandang individu yang memiliki gangguan mental dengan lebih objektif, serta dituntut untuk menginternalisasi nilai tersebut secara tidak langsung, hasil penelitian ini menunjukkan bahwa informasi mengenai gangguan mental dapat menurunkan penilaian mereka terhadap daya tarik fisik seseorang, baik secara objektif maupun subjektif. Dari sini, peneliti melihat bahwa partisipan penelitian yang mempelajari ilmu Psikologi tidak serta merta bisa dipastikan dapat memandang individu dengan gangguan mental secara netral dalam konteks yang menyangkut isu personal, dalam hal ini ketertarikan fisik dalam konteks romantis.

Hal ini dapat dijelaskan oleh pemahaman bahwa penilaian terhadap daya tarik fisik bukan sesuatu yang berdiri sendiri, namun erat terkait dengan kualitas-kualitas lain dari individu tersebut, seperti kepandaian dan kesuksesan dalam pekerjaan (Dion dkk., 1972; Eagly dkk., 1991; Langlois dkk., 2000). Adanya kualitas-kualitas ini pada laki-laki dapat memicu ketertarikan romantis perempuan, karena kualitas-kualitas tersebut akan mampu mendukung peran laki-laki dalam relasi romantis sesuai pandangan sosial. Peran yang dimaksud adalah sebagai pemberi nafkah untuk keluarga (Loscocco \& Spitze, 2007). Berdasarkan penjelasan ini, secara umum, sulit bagi partisipan untuk melepaskan penilaian daya tarik fisik dari keterkaitannya dengan aspekaspek kualitas laki-laki sebagai calon pasangan dalam konteks hubungan romantis. Konsekuensinya, saat manipulasi berupa informasi mengenai status gangguan mental yang erat dengan atribut-atribut negatif (Link dkk.; Nunnally; Olmsted \& Durham dalam Phelan \& Link, 2004) disampaikan kepada partisipan, penilaian mereka terhadap daya tarik fisik model laki-laki pada foto pun jadi cenderung menurun.

Penelitian ini juga menunjukkan bahwa penilaian partisipan terhadap daya tarik fisik model tidak terlepas dari bias, lebih spesifiknya bias negatif, meskipun mereka sudah memiliki pengetahuan yang cukup mengenai gangguan mental. Menurut Rozin dan Royzman (2001), individu cenderung memberikan penekanan yang lebih besar terhadap hal-hal negatif dibandingkan hal-hal positif dalam melihat sesuatu. Pada penelitian ini, kelompok kontrol menerima stimulus yang positif, yaitu foto laki-laki normal, dalam arti tidak memiliki gangguan mental, dengan daya tarik fisik yang tinggi. Pada kelompok eksperimen, selain menerima stimulus yang positif berupa foto laki-laki dengan daya tarik fisik yang tinggi, partisipan juga menerima stimulus yang negatif, yaitu informasi mengenai status gangguan mental yang dimiliki laki-laki pada foto.

Dalam penelitian ini, saat dihadapkan dengan suatu stimulus yang sepenuhnya bersifat positif, partisipan dengan sendirinya hanya akan menggunakan informasi tersebut sebagai dasar memberikan penilaian terhadap daya tarik fisik terhadap model pada foto. Namun, saat dihadapkan dengan dua stimulus yang sifatnya positif dan negatif sekaligus, informasi yang negatif akan cenderung lebih dipertimbangkan dalam memberikan penilaian. Oleh karena itu, meskipun model pada foto memiliki daya tarik fisik yang tinggi (stimulus positif), partisipan akan cenderung memberikan penilaian akhir terhadap daya tarik fisik tersebut berdasarkan status gangguan mental yang dimiliki model (stimulus negatif).

Perbedaan penilaian yang diberikan oleh partisipan di kelompok kontrol dan kelompok eksperimen dapat dijelaskan berdasarkan teori prospek yang dikemukakan oleh Kahneman \& Tversky (1979). Teori tersebut menjelaskan bahwa bias negatif erat kaitannya dengan penghindaran kerugian, yaitu kecenderungan individu untuk menghindari kerugian dibandingkan memperoleh keuntungan dalam menimbang sesuatu (Tversky \& Kahneman, 1991). Jika dikaitkan dengan penelitian ini, saat memberikan penilaian akhir terhadap daya tarik fisik model pada foto, partisipan pada kelompok eksperimen dapat dikatakan cenderung menghindari kerugian. Dalam konteks ketertarikan romantis seperti saat mencari calon pasangan, adanya gangguan mental dapat dianggap merugikan karena terkait dengan penurunan atau bahkan hilangnya fungsi personal dan interpersonal (APA, 2013). Hal ini sekaligus dapat menambah wawasan untuk studi mengenai penghindaran kerugian, yaitu bahwa objek yang menjadi pembahasan tidak terbatas pada barang atau materi yang berwujud seperti uang (Rozin \& Royzman, 2001), melainkan bisa juga berupa aspek yang tidak berwujud seperti trait individu, dan bagaimana aspek sosial mempengaruhinya.

Lebih lanjut, berdasarkan perhitungan effect size, pengetahuan tentang status mental lebih besar pengaruhnya pada penilaian daya tarik fisik seseorang secara subjektif. Hal ini dapat didasari pada dua proses kognitif yang dilibatkan dalam penilaian daya tarik, yaitu "Sistem 1" atau yang sifatnya lebih spontan dan "Sistem 2" atau yang sifatnya lebih terkontrol (Gawronski \& Creighton, 2013). Jika dikaitkan dengan kon- 
teks penelitian ini, pertimbangan yang dilakukan saat menilai daya tarik fisik subjektif ("seberapa menarik") memang lebih kompleks dibandingkan saat menilai daya tarik fisik objektif ("seberapa tampan"). Saat partisipan diminta untuk menilai secara objektif, mereka hanya mengandalkan inderanya, atau apa yang dilihat oleh matanya secara langsung tanpa mempertimbangkan hal lain.

Berbeda ketika partisipan diminta untuk menilai model secara subjektif, yaitu tidak hanya terpaku pada fitur wajahnya tetapi juga mempertimbangkan aspek lain yang tidak dilihatnya secara langsung. Di sini, partisipan akan mengacu pada informasi status mentalnya, sebagai satusatunya informasi tentang model yang mereka ketahui, dan cara memaknai informasi tersebut akan berbeda pada masing-masing partisipan. Informasi tersebut akan lebih berpengaruh pada caranya dalam menilai daya tarik fisik model, karena secara tidak langsung hal ini akan mempengaruhi penilaian seseorang dalam pemilihan pasangan-seperti yang dijelaskan dalam pembahasan sebelumnya bahwa pertimbangan untuk memilih pasangan tidak hanya dari tampilan fisik seseorang tetapi juga dari kesehatan yang dimilikinya.

Hal lain yang menjadi pembahasan pada penelitian ini adalah terdapat dua partisipan di kelompok eksperimen yang mengetahui bahwa model memang memiliki perilaku yang mengarah pada gangguan mental berdasarkan informasi yang diberikan oleh peneliti. Namun, keduanya memberikan pernyataan di lembar manipulation check bahwa raut muka model tampak normal dan merasa bahwa model tersebut tidak sewajarnya memiliki gangguan mental. Secara khusus, salah satu partisipan mengungkit bahwa senyuman yang ditampilkan oleh model tampak tidak dipaksakan, selayaknya senyuman orang pada umumnya.

Teori klasik mengenai ekspresi menyatakan bahwa arti di balik senyuman adalah kebahagiaan (Ekman \& Friesen, dalam Kraut \& Johnson, 1979). Seseorang yang merasa senang cenderung menampilkan senyuman kecuali dirinya ingin menutupi hal tersebut (Kraut \& Johnson, 1979). Kebahagiaan sendiri merupakan salah satu aspek penting dalam kesehatan (Cohn dkk., 2009) dan kesejahteraan atau well-being seseorang (Honkanen dkk., 2005). Di sisi lain, kesejahteraan atau well-being tersebut menunjukkan hubungan yang negatif dengan gejala gangguan mental (Keyes dalam Rahman dkk., 2016), sehingga dapat dikatakan bahwa individu dengan gangguan mental memiliki tingkat wellbeing yang rendah.

Atas dasar ini, sebagian orang mungkin memiliki persepsi bahwa individu yang bisa berbahagia dan tersenyum adalah individu yang normal dan tidak memiliki gangguan mental, dan sebaliknya, individu yang memiliki gangguan mental kurang bisa berbahagia dan tersenyum. Mereka merasa bahwa individu dengan gangguan mental tidak sewajarnya tersenyum, tetapi lebih mungkin untuk menunjukkan eskpresi sedih atau murung karena permasalahan yang dialaminya. Padahal, menurut penelitian yang dilakukan oleh Tron dkk. (2015), individu dengan gangguan skizofrenia pun masih bisa tersenyum, meskipun dengan intensitas yang lebih sedikit.

Berdasarkan diskusi hasil penelitian yang telah dijabarkan di atas, peneliti menyadari bahwa hasil penelitian ini masih dapat dikaji lebih lanjut pada penelitian selanjutnya. Peneliti merekomendasikan penelitian selanjutnya untuk melakukan penelitian serupa pada konteks personal lain di luar daya tarik dalam konteks romantis. Peneliti juga merekomendasikan penelitian selanjutnya untuk menggunakan kelompok sampel lain yang masih relevan, misalnya orangorang dengan latar belakang ilmu Psikologi yang sudah bekerja di bidang Psikologi pula. Kontrol terhadap latar belakang etnis partisipan perlu dipertimbangkan karena etnis seringkali sulit dilepaskan dari konteks ketertarikan fisik. Selain itu, penting untuk memperhatikan detil manipulasi yang diberikan pada saat eksperimen, misalnya memilih model dengan ekspresi netral untuk ditampilkan pada partisipan.

Lebih lanjut, ada keterbatasan yang perlu disadari terkait desain eksperimental yang digunakan dalam penelitian ini. Penelitian ini dijalankan dalam kondisi laboratori terkontrol dengan penekanan kekuatan pada validitas internal untuk menjelaskan hubungan sebab akibat yang bersifat esensial antarvariabel, sehingga penerjemahan hasilnya ke dalam kondisi nyata di lapangan perlu dilakukan dengan hati-hati. Selain itu, terkait kontrol variabel sekunder, walaupun penelitian ini telah berusaha melakukan kontrol ketat terhadap variabel sekunder yang diprediksi dapat mempengaruhi hasil penelitian, kemungkinan adanya variabel lain yang dapat mempengaruhi hasil penelitian di luar prediksi tetap perlu disadari dan dipertimbangkan dalam studi selanjutnya.

Penelitian ini memiliki implikasi untuk memberikan gambaran mengenai tantangan yang dapat dihadapi individu-individu dengan gangguan mental, khususnya dalam konteks hubungan romantis, mengingat penilaian terhadap daya tarik fisik mereka dapat menurun seturut terbukanya status gangguan mental mereka. Implikasi lain dari penelitian ini adalah untuk meningkatkan kesadaran bahwa, bahkan pada orang-orang yang berkuliah S1 Psikologi, dapat terjadi kesenjangan yang esensial antara pemahaman 
mengenai gangguan mental dengan penilaian, dalam hal ini penilaian mengenai daya tarik fisik, yang diberikan terhadap individu dengan gangguan mental. Artinya, pemahaman yang dimiliki mengenai gangguan mental perlu diimbangi dengan kepekaan terkait bias-bias yang mungkin muncul saat melakukan penilaian terhadap individu-individu dengan gangguan mental, agar penilaian yang akhirnya diberikan tidak merugikan mereka.

\section{Kesimpulan}

Penelitian ini ingin melihat pengaruh informasi tentang status gangguan mental terhadap penilaian daya tarik fisik pada mahasiswi S1 Psikologi, dengan sampel mahasiswi S1 FPUAJ. Hasil penelitian ini menunjukkan adanya pengaruh informasi tentang status gangguan mental terhadap penilaian daya tarik fisik. Partisipan pada kelompok eksperimen yang diberikan manipulasi berupa informasi yang menunjukkan bahwa model memiliki gangguan mental, menurunkan skor daya tarik fisik yang mereka berikan terhadap model saat posttest. Kelompok kontrol yang tidak diberi manipulasi berupa informasi yang menunjukkan bahwa model memiliki gangguan mental, memberikan skor yang relatif sama saat pretest dan posttest. Selisih skor dari masingmasing kelompok eksperimen dan kelompok kontrol ini berbeda secara signifikan berdasarkan perhitungan analisis statistik. Hal ini berlaku baik untuk daya tarik fisik objektif maupun daya tarik subjektif. Lebih lanjut, perhitungan effect size menunjukkan bahwa informasi tentang status gangguan mental memiliki pengaruh yang lebih besar terhadap daya tarik fisik subjektif ("seberapa menarik") dibandingkan daya tarik fisik objektif ("seberapa tampan").

\section{Ucapan Terima Kasih}

Terima kasih sebesar-besarnya kepada seluruh partisipan beserta model penelitian, baik yang terpilih maupun tidak terpilih, atas keterlibatannya dalam penelitian ini. Terima kasih kepada Christ Billy Aryanto atas masukanmasukan berharga yang diberikan kepada peneliti saat sedang merancang penelitian ini.

\section{Daftar Pustaka}

Abdullah, T. \& Brown, T. L. (2011). Mental illness stigma and ethnocultural beliefs, values, and norms: An integrative review. Clinical Psychology Review, 31, 934-948. https://doi.org/10.1016/j.cpr.2011.05. 003

American Psychiatric Association. (2013). Diagnostic and statistical manual of mental disorders (5 $5^{\text {th }}$ ed.). Arlington, VA: American Psychiatric Publishing.

Axelsson, J., Sundelin, T., Ingre, M., Van Someren, E. J., Olsson, A., \& Lekander, M. (2010). Beauty sleep: experimental study on the perceived health and attractiveness of sleep deprived people. BMJ, 341, 1287-1289. https://doi.org/10.1136/bmj.c6614

Boysen, G. A. (2017). Stigma toward people with mental illness as potential sexual and romantic partners. Evolutionary Psychological Science, 3(3), 212-223. https://doi.org/10.1007/s40806-0170089-5

Cohn, M. A., Fredrickson, B. L., Brown, S. L., Mikels, J. A., \& Conway, A. M. (2009). Happiness unpacked: Positive emotions increase life satisfaction by building resilience. Emotion, 9, 361368. https://doi.org/10.1037/a001595 2

Dion, K., Berscheid, E., \& Walster, E. (1972). What is beautiful is good. Journal of Personality and Social Psychology, 24(3), 285-290. https://doi.org/10.1037/h0033731

Eagly, A. H., Ashmore, R. D., Makhijani, M. G., \& Longo, L. C. (1991). What is beautiful is good, but...: A meta-analytic review of research on the physical attractiveness stereotype. Psychological Bulletin, 110(1), 109-128. https://doi.org/10.1037/00332909.110.1.109

Farina, A., Fischer, E. H., Sherman, S., Smith, W. T., Groh, T., \& Mermin, P. (1977). Physical attractiveness and mental illness. Journal of Abnormal Psychology, 85(5), 510-517. https://doi.org/10.1037/0021843X.86.5.510

Feingold, A. (1992). Good-looking people are not what we think. Psychological Bulletin, 111(2), 304-341. https://doi.org/10.1037/00332909.111.2.304

Gawronski, B., \& Creighton, L. A. (2013). Dual process theories. Dalam D. E. Carlston (Ed.), The Oxford handbook of social cognition, 282-312, New York, NY, US: Oxford University Press.

Hirai, M., \& Clum, G. A. (2000). Development, reliability, and validity of the beliefs 
toward mental illness scale. Journal of Psychopathology and Behavioral Assessment, 22, 221-236. https://doi.org/10.1023/A:100754843 2472

Honkanen, H., Jaakko Kaprio, J., Honkanen, R., Viinamaki, H., Koskenvuo, M., (2005). The stability of life satisfaction in a 15years follow-up of adult Finns healthy at baseline. BioMed Cent. Psychiatry, 5 (4). https://doi.org/10.1186/1471244X-5-4

Jonason, P. K., Garcia, J. R., Webster, G. D., Li, N. P., \& Fisher, H. E. (2015). Relationship dealbreakers: Traits people avoid in potential mates. Personality and Social Psychology Bulletin, 41(12), 1697-1711. https://doi.org/10.1177/01461672156 09064

Jorm, A. F., Barney, L. J., Christensen, H., Highet, N. J., Kelly, C. M., \& Kitchener, B. A. (2006). Research on Mental Health Literacy: What we know and what we Still Need to know. Australian \& New Zealand Journal of Psychiatry, 40(1), 35. https://doi.org/10.1080/j.14401614.2006.01734.x

Kahneman, D., \& Tversky, A. (1979). Prospect theory: An analysis of decisions under risk. Econometrica, 47, 263-291. https://doi.org/10.2307/1914185

Kraut, R. E., \& Johnston, R. E. (1979). Social and emotional messages of smiling: An ethological approach. Journal of Personality and Social Psychology, 37(9), 1539-1553. https://doi.org/10.1037/00223514.37.9.1539

Langlois, J. H., Kalakanis, L., Rubenstein, A. J., Larson, A., Hallam, M., \& Smoot, M. (2000). Maxims or myths of beauty? A meta-analytic and theoretical review. Psychological Bulletin, 126(3), 390-423. https://doi.org/10.1037/00332909.126.3.390

Loscocco K, \& Spitze G. (2007). Gender Patterns in Provider Role Attitudes and Behavior. Journal of Family Issues. 28(7),934-954. https://doi.org/10.1177/0192513X07 300787

Maher, J. M., Markey, J. C., \& Ebert-May, D. (2013). The other half of the story: effect size analysis in quantitative research. $C B E \quad$ life sciences education, 12(3), 345-351. https://doi.org/10.1187/cbe.13-040082
Matusitz, J. (2012). Relationship between knowledge, stereotyping, and prejudice in interethnic communication. Revista de Turismo y Patrimonio Cultural, 10(1), 89-98. https://doi.org/10.25145/j.pasos.2012 .10 .008

Overton, S. L. \& Medina, S. L. (2008). The stigma of mental illness. Journal of Counseling \& Development, 86, 143-151. https://doi.org/10.1002/j.15566678.2008.tb00491.x

Phelan, J. C. \& Link, B. G. (2004). Fear of people with mental illnesses: the role of personal and impersonal contact and exposure to threat or harm. Journal of Health and Social Behavior, 45, 68-80. https://doi.org/10.1177\%2F00221465 0404500105

Rahman, S., Ansari, S.A., \& Parveen, F. (2016). Happiness as correlates of mental wellbeing. The International Journal of Indian Psychology, 3(3), 157-163. https://doi.org/10.25215/0303.094

Rhodes, G. (2006). The evolutionary psychology of facial beauty. Annual Reviews of Psychology, 57, 199-226. https://doi.org/10.1146/annurev.psyc h.57.102904.190208

Rozin, P., \& Royzman, E. B. (2001). Negativity bias, negativity dominance, and contagion. Personality and Social Psychology Review, 5(4), 296320. https://doi.org/10.1207/S153279 57PSPR0504_2

Shoemake, E. G. (2007). Human mate selection theory: An integrated evolutionary and social approach. Journal of Scientific Psychology, 35-41.

Sternberg, R. J. \& Sternberg, K. (2011). Cognitive psychology ( $6^{\text {th }}$ ed.). Belmont, CA: Wadsworth.

Time to Change. (14/09/2010). Unlucky in love? Try dating with a mental illness. Diunduh dari https://www.time-tochange.org.uk/news/unlucky-love-trydating-mental-illness

Tron, T., Peled, A., Grinsphoon, A., \& Weinshall, D. (2015). Automated Facial Expressions Analysis in Schizophrenia: A Continuous Dynamic Approach. Pervasive Computing Paradigms for Mental Health, 72-81. https://doi.org/10.1007/978-3-31932270-4_8

Tversky, A., \& Kahneman, D. (1991). Loss aversion in riskless choice: A referencedependent model. The Quarterly Journal of Economics, 106(4), 1039- 
1061.

https://doi.org/10.2307/2937956

Wahl, O., Susin, J., Lax, A., Kaplan, L., \& Zatina,

D. (2012). Knowledge and attitudes about mental illness: A survey of middle school students. Psychiatric Services, 63(7), 649-654.

https://doi.org/10.1176/appi.ps.20110 0358 